\title{
LOCAL COMMUNITY PARTICIPATION IN RECREATION AND MENTAL HEALTH EXPERIENCES: A CASE STUDY OF THE EASTERN CAPE PROVINCE - SOUTH AFRICA
}

\author{
Acha-Anyi Paul NKEMNGU* \\ Walter Sisulu University, Buffalo City - College Street Campus, Faculty of Business Science, Department of Tourism, \\ Hospitality and Sports Management, 88 Buffalo Street, East London, 5201, South Africa, e-mail: Pacha-anyi@wsu.ac.za
}

\begin{abstract}
Citation: Acha-Anyi, P.N. (2020). LOCAL COMMUNITY PARTICIPATION IN RECREATION AND MENT AL HEALTH EXPERIENCES: A CASE STUDY OF THE EASTERN CAPE PROVINCE - SOUTH AFRICA. GeoJournal of Tourism and Geosites, 31(3), 1153-1160. https://doi.org/10.30892/gtg.31329-552
\end{abstract}

\begin{abstract}
Research on the relationship between recreation and mental health has largely focused on individual recreation participation, despite the fact that a community approach to mental health has been widely advised. This study fills this research gap by exploring the relationship between recreation practice and mental health experiences within local communities in the Eastern Cape. Following quantitative data analysis, Mean values and analysis of variance were examined in order to compare mental health experiences, income levels and employment status among communities. The results reveal high mental health experiences but no statistically significant differences based on income or employment status were found. The study implications are discussed.
\end{abstract}

Key words: recreation, mental health, community, experiences, Eastern Cape Province

\section{INTRODUCTION}

Recreation, generally understood to refer to activities engaged in during discretionary time (Suárez et al., 2020; Aksoy et al., 2017), has long been associated with relaxation, rest, escape from the stress of daily routine work and rejuvenation. Dillette et al. (2020) assert that some people take the opportunity presented by leisure time to engage in their ultimate life pleasure. Within this context, tourism research has often alluded to the correlation between participation in recreational activities and health benefits (Langviniene, 2014; Pesonen et al., 2011; Nicolaides and Grobler, 2017). However, extant studies have cautioned against the assumption that every leisure engagement will result in a positive mental health experience (Rubenstein, 1980; Dolnicar et al., 2012; Filep, 2014; Marion et al., 2018). In this vein, the Global Wellness Institute concedes in its 2018 global wellness tourism economic report (Global Wellness Institute, 2018) that aspects of tourism such as flying could result in a decrease in the quality of health in some people. Lee and Fernando (2015) and Rundle et al. (2018) affirm that leisure engagement is riddled with activities that could potentially impact negatively on the physical and mental health of participants. In essence, these studies point to the heterogeneous nature of tourism and its key component, recreation and the subjective experiences that emanate thereof. The current study was motivated by, among others, the fact that previous research has examined the nexus between recreation and health mainly from the individual perspective, and secondly, the imperative that communities deserve to be studied within their specific socio-economic and geographical contexts in order to determine how participation in recreation impacts on their mental health.

The close association between leisure, recreation and tourism has often generated curiosity and scrutiny, but also a degree of misunderstanding. While unpacking the three words reveals that they are all part of the tourism fraternity, it should be clear that these terms should neither be used interchangeably nor as synonyms. Leisure is related to time as its key function, while recreation is linked to activities, and tourism is underpinned by movement between destinations (Leiper, 1979; Fletcher et al., 2018; Acha-Anyi, 2018; AchaAnyi, 2020). Hence, Tribe (2016) defines leisure as discretionary time available to an individual after all work and obligatory duties have been performed, and recreation as activities engaged in during leisure time. The relationship between leisure, recreation and tourism then emanates from the fact that leisure tourists move from their places of permanent residence to other destinations during their free time to engage in non-obligatory activities (recreation) for entertainment (Kerimbay et al., 2020; Fletcher et al., 2018; Tribe, 2016). This distinction is considered necessary in the current study as the goal is to explore the relationship between the respondents' participation in recreation activities within the local community and their mental health experiences.

Aliyeva et al. (2020) premise the distinguishing features of leisure and recreation on the mental state of the participant by clarifying that leisure is a state in which a person feels released from all mandatory or life sustaining duties, while recreation refers to an activity that refreshes, stimulates and relaxes the individual physically and/or mentally. From this perspective, it is evident that recreation is both universal and dates back to even pre-historic times. Nonetheless, recreation is neither uniform nor homogenous. On the contrary, recreation differs across cultures, individuals and destinations. Recreation can be undertaken individually or collectively as a community.

Research on recreation has identified three general features that are characteristic of recreation practice; which are all interconnected, but none of which can deliver the recreation experience in silo (Ferguson et al., 2019; Chukhu, 2020a; Gumus and Isik, 2018). First of all, recreation activity can only be practiced during the time that the participant feels they are free from any obligation and can exercise freedom of choice. Secondly, the participant should have access to at least one activity on which they can engage, such as sport, walking, spending time at the beach front, watching television, reading a book, among others. It is worth noting that an activity that is considered work by one person can be perceived as recreation activity by the other. Examples of such activities include sports, stage performances, driving, etc. Thirdly, recreation can be considered existentialistic, or being a state of mind within which the individual is free or liberated from time or activity consciousness, apart from the meaning attributed to it by the individual participant. Put differently, the activity is considered recreation simply because the individual participant feels it is. These attributes of recreation are important to this study for two reasons: firstly, at the emotional level, collecting the views of the respondents during recreation participation will be useful in authenticating their recreation perceptions; and secondly, at the activity level, the study will be able to relate the recreation participation to the mental health experiences. Furthermore, it is important to 
contextualise the mental health background from which the respondents originate in order to adequately assess their recreation experience. Hence, the mental health situation in South Africa, in general and the Eastern Cape province in particular is discussed below.

\section{LITERATURE REVIEW}

\section{Mental health - The South African context}

South Africa has accomplished major strides in harnessing its policy commitment towards improving the quality of mental health in local communities (Petersen, 2000; Matlala et al., 2018; Bimerew, 2019). The dawn of the democratic dispensation in 1994 ushered in a new policy directive that sort to prioritise mental health as an indispensable component of the health package (Department of Health, 1997). Indeed, the attainment of this laudable goal would align South Africa with the World Health Organisation's definition of heal th as, "a state of complete physical, mental and social wellbeing and not merely the absence of disease or infirmity (World Health Organisation, 2018). In essence, the invigoration of the mental health drive in South Africa sprang into action with the publication of the White paper for the transformation of the health system in 1997 (Department of Health, 1997). The mental health policy guidelines which accompanied the White paper on health articulated how mental health would be delivered as part of Primary Health Care (PHC), (Department of Health, 1997).

However, despite the number of policy interventions that have been made to enhance mental health since 1994, the adoption of the National Mental Health Policy Framework and Strategy Plan 2013-2020 stands out as the defining moment in the fight to improve the mental health situation within communities (Department of Health, 2013). The significance of the enactment of the National Mental Health Policy Framework and Strategy Plan 2013-2020 lies, inter alia, in the fact that it brings in to focus previous policy initiatives, but more importantly, this piece of legislation formally endorsed and elevated quality mental health to its rightful position as a Human right alongside physical wellbeing in line with international requirements (Department of Health, 2013; United Nations Development Programme, 2015; World Health Organisation, 2018). However, despite the commendable policy interventions towards the attainment of quality mental health in South Africa, evidence from local communities suggests the achievement of the goal remains quite elusive (Petersen, 2000; Lund et al., 2010; Burns, 2011; South African College of Applied Psychology, 2020). The National Mental Health Policy Framework and Strate gic Plan 2013-2020 reveals that neuropsychiatric disorders constitute the third burden of disease in South Africa, with the most prevalent mental disorder being anxiety disorder (15.8\%), followed by substance use disorder (13.3\%) and mood disorders (9.8\%) (Herman et al., 2009; Department of Health, 2013). The South African Depression and Anxiety Group further reports that 21.4\% of teenagers in South Africa have considered committing suicide (South African Depression and Anxiety Group, 2020). From a policy implementation perspective, a number of gaps have been acknowledged, among which are the fact that mental health has been underfunded and under-resourced (Bradshaw et al., 2007; Lund et al., 2011; Department of Health, 2013). According to Lund and Flisher (2009) the great disparity between provinces in the allocation of mental health services and resources has also aggravated the situation. Moreover, public awareness regarding mental health conditions is low and stigmatisation of affected people is rife. The National Mental Health Policy Framework and Strategy Plan 2013-2020 (Department of Health, 2013) acknowledges that the absence of accurate data due to poor data collection has also hampered efforts to fast track quality mental health interventions. The persistent misunderstanding among some community members that mental health refers to the existence of mental illness continues to discourage some people from seeking assistance timeously (Lund et al., 2011).

\section{Mental health - the Eastern Cape provincial context.}

With a population of approximately seven million inhabitants, the Eastern Cape province is ranked third, after Gauteng and KwaZulu Natal in number of inhabitants per province in South Africa (Statistics South Africa, 2016). The topography of the province is mainly mountainous with deep valleys in between. The economy of the Eastern Cape province evolves around major industrial hops such as the Mercedes Benz manufacturing plant and Nestle factory, agriculture, and its $800 \mathrm{~km}$ coastline punctuated by pristine, unspoilt beaches. Administratively, the Eastern Cape province is made up of two metropolitan Municipalities (Buffalo City Metropolitan Municipality and Nelson Mandela Bay Metropolitan Municipality) and six District Municipalities, namely: Alfred Nzo District Municipality, Amathole District Municipality, Chris Hani District Municipality, Joe Gqabi District Municipality, OR Tambo District Municipality and Sarah Baartman District Municipality. The mental health situation in the Eastern Cape province is not different from the rest of South Africa, considering that the mental illness prevalence rate is 16.8\% (Sukeri, 2015; Andersson et al., 2013), just slightly higher than the national prevalence rate of 16.7\% (Skeen and Lund, 2019; South African Drug and Anxiety Group, 2020). However, the province has been profiled as having several high-risk factors that could aggravate its mental health situation (Strümpher et al.. 2016; Madala-Witbooi et al., 2019; Ramugondo et al., 2017), among which are the high percentage of people living below the upper-bound poverty line (UBPL) of $(67,3 \%$ ) above the national average of $49.2 \%$ (Stats SA, 2019), high unemployment rate of 35.6\% (Eastern Cape Socio-Economic Consultative Council, 2019), stigma associated with mental illness and lack of adequate health care professionals (Sukeri, 2015; South African Human Right Commission 2017). Socio-economic factors such as poverty, low levels of education and unemployment have demonstrated a high correlation with poor mental health, hence the prevailing conditions increase the vulnerability of the Eastern Cape province to mental health challenges (Sukeri, 2015). Moreover, all 15 licensed mental healthcare facilities are located in the urban areas, leaving the rural population under-resourced (South African Human Right Commission, 2018). Stigma and discrimination are also contributing factors to the prevalence of mental illness in the province (Ramugondo et al., 2017).

\section{Mental health - COVID-19 as the aggravating factor}

It comes as no surprise that the current COVID-19 pandemic and the infamous "lockdown" phenomenon have increased the vulnerability of community members to mental health challenges. The South African Depression and Anxiety Group (SADAG) has confirmed receiving an increased number of telephone calls from distressed people under emotional strain of financial hardship, relationship problems, job security, grief, gender based violence and trauma (South African Depression and Anxiety Group, 2020). Furthermore, statistics South Africa (Statistics South Africa) reports that during the first six weeks of the national lockdown, the percentage of people who reported receiving no income rose from 5.2\% to 15.4\% (Statistics South Africa, 2020). Similarly, the number of people going without food in South Africa increased since the declaration of the COVID-19 pandemic from 4.3\% to 11.4\% (Statistics South Africa, 2020). The United Nations Development programme and the Food and Agriculture Organisation assert that food secu rity is both a human right and an important aspect of human dignity (United Nations Development Programme, 2015, 2015; Food and Agriculture Organization, 2020). It seems obvious that managing the mental health demands of South Africa is going to require innovative approaches that could complement the existing policy framework.

\section{Theoretical background}

The theoretical background of this study is rooted in extant research (Wang et al., 2013; Hartwell, 2015; Dillette et al, 2020; White and Eyber 
(2017); Aksoy et al., 2017) that has identified mental health as a key variable in the analysis of wellbeing. The notion of wellbeing has been associated with wellness which epitomises a healthy state of mind, body and spirit (Myers et al., 2000; Lobo, 2011; Kolappa et al., 2013). The National Wellness Institute adopts a more transient approach as it deviates from the notion of wellness as a state and defines wellness as "an active process through which people become aware of, and make choices towards a more successful existence" (National Wellness Institute, 2009). While conceptual debates are a necessary part of academic research, suffice to establish that a holistic view of the wellness concept brings mental, physical and spiritual health in to the same lens and focus. As the dependent variable in this study, mental health is a subset of both health and wellbeing. Though more subtle and inward-looking, mental health is invariably the foundation on which other aspects of wellbeing (physical and spiritual) thrive (World Health Organisation, 2018; National Wellness Institute, 2009). Put bluntly, there is "no health without mental health" (Kolappa et al., 2013; Hartwell, 2015; World Health Organisation, 2018). Mental health provides stability, bal ance and integrity in the individual (World Health Organisation, 2018). Furthermore, the fact that mental health is generally expressed as a positive resource or state of being creates a tendency in some people to use mental health interchangeably with wellbeing, wellness or even happiness (Dillette et al., 2020).

Research has identified two major aspects of mental health as the hedonic dimensions being the expression of good feelings (happiness) and the eudaimonic dimensions related to welfare or ability to function optimally (Ryan and Deci, 2001; Stewart-Brown, 2015; Tamminen et al., 2020). The two dimensions are not mutually exclusive, but rather complement each other in the realisation of positive mental health. According to Huppert (2009), Vaillant (2012) and Tamminen et al. (2020) positive mental health is expressed as a function of self-esteem, optimism, coherent actions, positive relationships, ability to cope with adverse situations, happiness, contentment and resilience. Research on positive mental health has gained impetus among various health and community welfare institutions such as the World Health Organisation, national governments, policy makers, health practitioners and individuals with the commitment to achieve quality health and wellbeing for their people (Hartwell, 2015; White and Eyber, 2017; Aksoy et al., 2017). It is therefore, to this end that the current study has adopted six of the salient mental health attributes (happiness, concentration, relationships, purpose, goal orientation and peace with self as key variables in exploring the nexus between recreation participation among community members and mental health experiences.

\section{MATERIALS AND METHODS}

The purpose of this study was to explore the relationship between participation in recreation within Eastern cape communities (municipalities) and mental health experiences. Considering the prevailing challenges to the attainment of quality mental health in the province, the aim was to ascertain the extent to which community participation in recreation could impact on mental health ex perience of the respondents. To get the views of as many community members as possible, a questionnaire was developed and distributed during four community recreation events, namely; visits to the eastern beach front, the Berlin November horse race in Berlin - Buffalo City Metropolitan Municipality, a church event in Butterworth in Amatole District municipality, and a community football match in Mdanstane township. The research instrument, data collection, unit of analysis and data analysis were executed as follows:

Study instrument

The questionnaire that was used for data collection was divided in two sections; section A - measuring the respondents' experiences of various mental health attributes during the recreation activity, and section B - gathering demographic information on the respondents. The reason for putting the questions on mental health experience (section A) before the demographic characteristics of the respondents was to increase the chances of getting the respondents to provide responses to all the questions by completing the personal questions towards the end. Key literature consulted in order to determine the mental health variables was informed by Hartwell (2015); White and Eyber (2017); Datta (2020) and Dillette et al. (2020). The demographic variables served to provide a socio-economic context to the mental health experiences of the respondents. The three way categorisation of the demographic variable, household income, deserves particular reference as it followed Statistics South Africa's description of upper bound of poverty line threshold of R1227 (amount of money required to purchase food and other life-essentials per person per month at 2019 prices) (Statistics South Africa, 2019). In this regard, annual household income was estimated and categorised as follows: below the poverty line (below R25, 000), above the poverty line (R25, 000 - R100, 000) and middle income and above (more than R100, 000).

Data collection

Data collection was done during four recreation activities identified as: spending time at a beach front in East London, the Berlin November horse racing event in Buffalo City Metropolitan Municipality, watching a football match in Mdantsane township and participating in a church event in Butterworth municipality. Data collection at the beach front in East London took place over four weekends between the 10 of November to 15 December 2019, while the collection of data at the other three events (Berlin November horse race, Mdanstane football match, and church event in Butterworth) took place over one day (30 of November 2019, 6 of December 2019 and 14 of December 2019, respectively). Five field workers were trained in preparation for the data collection. To qualify for the training and subsequent data collection, interested candidates had to meet the criteria of having completed at least a National diploma qualification to ensure that they can understand and explain the questionnaire and also demonstrate proficiency in the local language (Xhosa) in order to be able to communicate with the local people who may not understand English. The training focused on explaining the questionnaire and respecting ethical guidelines in data collection. The data collection procedure involved randomly approaching participants at the above mentioned events and asking them if they would be willing to participate in the study. Participants who consented to taking part in the study were handed the questionnaire and a pen to express their views. Each completed questionnaire was checked for errors and stored in a safe place.

Unit of analysis

The term unit of analysis has been defined as the entity that constitutes the focus of the study (Mouton, 2013). This study focuses on understanding how participation in recreation at community level impacts on participants' mental health experiences. Even though data was collected from individual community members, the analysis and focus of the research is on the community from which the respondents originate. To this effect, the questionnaire gathered information on the community of origin of the respondents and the data was subsequently categorised according to which of the eight municipalities of the Eastern Cape province the respondents came from. The community approach was preferred in this study because it is largely recommended in addressing mental health challenges (World Health Organisation, 2013; Department of Health, 2013; Sukeri, 2015; Aksoy et al., 2017).

Data analysis

Following Creswell and Clark (2011), the data analyses involved reducing the quantitative data sets to manageable sizes in order to explore underlining patterns. To this end, the 247 duly completed questionnaires were captured in Microsoft ${ }^{\circledR}$ Excel ${ }^{\circledR}$ spreadsheet and analysed using the IBM Statistical Package for Social Sciences (SPSS), version 25. It is worthy of note that of the 261 returned questionnaires, 14 were discarded as they were either not completed in full or had multiple answers selected. The descriptive analyses of frequencies and percentages were performed to obtain the demographic profile of the respondents, while mean values and analysis of 
variance (ANOVA) were performed to find out if there were any statistically significant differences in the respondents' mental health experiences based on demographic aspects such as income level and employment status. The effect sizes were also examined.

\section{RESULTS AND DISCUSSION}

The results of the study are presented in three sections below, starting with the descriptive statistics on the demographic profile of the respondents, a discussion on the mean values of the mental health experiences and the analysis of variance between the independent variables income level and employment status.

\section{Demographic profile of the respondents}

The results presented in Table 1 below indicate that majority of the respondents (40\%) came from Buffalo City Metropolitan Municipality, followed by the O.R Tambo District Municipality (20\%) and Chris Hani District Municipality (14\%). This is not surprising because most of the data, as seen from the item "respondent recreation activity", was collected at the beach front (56\%) in Buffalo City Metropolitan Municipality. The results also reveal that more men (57\%) than females (43\%) took part in the study, and that most of the respondents $(41 \%)$ were within the age group of 21 and 30 years, followed by those aged between $31-40$ years old (22\%) and younger people between the ages of $18-20$ years. This information indicates that most of the recreation participants who took part in this study are young and still quite active. From an economic perspective, the results indicate that most of the respondents were either unemployed (35\%) or self-employed (30\%). Among those employed, $24 \%$ were government employees while $11 \%$ worked in the private sector. This data seems to confirm the high rate of unemployment in the Eastern Cape province, especially among the youth (Statistics South Africa, 2019). Although the household income of most of the respondents (56\%) is within the upper bound of poverty line (Statistics South Africa, 2019), 36\% of the respondents indicate that they live below this income threshold. With regards to the level of education, most of the respondents (39\%) have obtained the school leaving certificate (Matric), while 25\% have completed a Diploma course.

Table 1. Demographic profile of recreation participants

\begin{tabular}{|c|c|c|c|}
\hline Demographic characteristic & Category & Frequency $(\mathrm{N})$ & Percentage \\
\hline \multirow{8}{*}{$\begin{array}{l}\text { Municipality of } \\
\text { origin }\end{array}$} & Buffalo City Metropolitan Municipality & 99 & $40 \%$ \\
\hline & Chris Hani District Municipality & 35 & $14 \%$ \\
\hline & OR Tambo District Municipality & 49 & $20 \%$ \\
\hline & Nelson Mandela Bay Metropolitan Municipality & 11 & $4 \%$ \\
\hline & Joe Gqabi District Municipality & 16 & $7 \%$ \\
\hline & Alfred Nzo District Municipality & 7 & $3 \%$ \\
\hline & Amathole District Municipality & 23 & $9 \%$ \\
\hline & Sarah Baartman District Municipality & 7 & $3 \%$ \\
\hline \multirow{2}{*}{ Gender } & Female & 107 & $43 \%$ \\
\hline & Male & 140 & $57 \%$ \\
\hline \multirow{6}{*}{ Age } & $18-20$ & 53 & $22 \%$ \\
\hline & $21-30$ & 102 & $41 \%$ \\
\hline & $31-40$ & 53 & $22 \%$ \\
\hline & $41-50$ & 25 & $9 \%$ \\
\hline & $51-60$ & 13 & $5 \%$ \\
\hline & $60+$ & 1 & $1 \%$ \\
\hline \multirow{4}{*}{ Employment status } & Unemployed & 86 & $35 \%$ \\
\hline & Self employed & 74 & $30 \%$ \\
\hline & Government employee & 59 & $24 \%$ \\
\hline & Private sector employee & 28 & $11 \%$ \\
\hline \multirow{6}{*}{ Education } & No schooling & 10 & $4 \%$ \\
\hline & Grade 1-11 & 23 & $9 \%$ \\
\hline & Matric & 96 & $39 \%$ \\
\hline & Diploma & 62 & $25 \%$ \\
\hline & Degree & 31 & $13 \%$ \\
\hline & Postgraduate & 25 & $10 \%$ \\
\hline \multirow{3}{*}{ Annual income } & $<\mathrm{R} 25,000$ & 89 & $36 \%$ \\
\hline & $\mathrm{R} 25,001-\mathrm{R} 100,000$ & 139 & $56 \%$ \\
\hline & $\mathrm{R} 100,000+$ & 19 & $8 \%$ \\
\hline \multirow{4}{*}{$\begin{array}{l}\text { Respondent recreation } \\
\text { activity }\end{array}$} & Beach walking & 138 & $56 \%$ \\
\hline & Watching a footbal match & 31 & 13 \\
\hline & Having fun at Berlin November Horse race & 48 & $19 \%$ \\
\hline & Participating at a church group day out & 30 & $12 \%$ \\
\hline
\end{tabular}

\section{Data reliability}

Prior to exploring the data set for underlying patterns and relationships between the variables, it (the data set) was tested for reliability to ensure internal consistency. This was done by running the data on IBM's Statistical Package for Social Sciences (SPSS), version 25. The results revealed an acceptable Cronbach's alpha score of .633 (Table 2), as it was above the threshold of 0.60 (Hair et al., 2006).

Table 2. Results of the data reliability Test

\begin{tabular}{|l|l|c|}
\hline \multicolumn{2}{|c|}{ Kaiser-Meyer-Olkin Measure of Sampling Adequacy } & .633 \\
\hline \multirow{3}{*}{ Bartlett's Test of Sphericity } & Approx. Chi-Square & 103.469 \\
\cline { 2 - 3 } & df & 15 \\
\cline { 2 - 3 } & Sig. & .000 \\
\hline
\end{tabular}

\section{Descriptive statistics}

The mean scores of the six factors under discussion (Table 3) clearly indicate that participants in recreation from the community who took part in this study consider happiness as the greatest experience (4.43). Among the communities or municipalities, respondents from the Nelson Mandela Bay Municipality experience the most happiness (4.64) from recreation participation, followed by those from Amathole District Municipality (4.61) and Alfred Nzo District Municipality (4.57). However, respondents from Chris Hani District 
Municipality with a mean value of 4.31 do not rate happiness as highly as respondents from the other seven municipalities. Evidence from the data indicates that respondents from the Chris Hani District Municipality attribute the greatest experience from recreation participation to be in the area of relationships (4.34). This is significant because the score of 4.34 is higher than the total mean (provincial mean considering that all municipalities in the province are involved) of 4.16 .

The second mental health factor with a high experience total mean score of 4.22 is "meaning and purpose". Under this factor, five municipalities (Nelson Mandela Bay Metropolitan Municipality (4.45), Joe Gqabi District Municipality (4.31), Sarah Baartman District Municipality (4.29) OR Tambo District Municipality (4.24) and Buffalo City Metropolitan Municipality (4.23) have mean scores above the total (provincial) mean of 4.22. It is, however, surprising that the experience of being able to improve concentration on work has the lowest total mean (3.93). One would expect that participation in recreation activities will have a positive correlation with concentration on work.

Table 3. Descriptive statistics for mental health experiences and community participation in recreation

\begin{tabular}{|c|c|c|c|c|c|c|c|c|c|c|c|c|}
\hline \multirow{2}{*}{$\begin{array}{l}\text { Mental health factor } \\
\text { Community of origin }\end{array}$} & \multicolumn{2}{|c|}{ Happy } & \multicolumn{2}{|c|}{ Concentrate } & \multicolumn{2}{|c|}{ Relationship } & \multicolumn{2}{|c|}{ Meaning \& purpose } & \multicolumn{2}{|c|}{ Progress } & \multicolumn{2}{|c|}{ Peace } \\
\hline & Mean & Std dev. & Mean & Std dev. & Mean & Std dev. & Mean & Std Dev. & Mean & Std dev. & Mean & Std dev. \\
\hline Buffalo city & 4.35 & .937 & 4.15 & .885 & 4.14 & .783 & 4.23 & .890 & 3.91 & .949 & 3.96 & 1.078 \\
\hline Chris Hani District Municipality & 4.31 & 1.022 & 3.51 & 1.422 & 4.34 & .684 & 4.11 & .963 & 4.06 & .838 & 4.14 & 1.115 \\
\hline $\begin{array}{l}\text { Nelson Mandela Bay Metropolitan } \\
\text { Municipality }\end{array}$ & 4.64 & .505 & 4.18 & 1.079 & 4.00 & .775 & 4.45 & .688 & 4.09 & .944 & 4.09 & .831 \\
\hline Joe Gqabi District Municipality & 4.56 & 1.103 & 3.75 & .931 & 4.38 & .500 & 4.31 & .793 & 3.94 & .772 & 3.75 & 1.183 \\
\hline Alfred Nzo District Municipality & 4.57 & 1.134 & 4.29 & .756 & 4.00 & .577 & 3.86 & .690 & 4.14 & .690 & 3.57 & .976 \\
\hline Amathole District Municipality & 4.61 & .499 & 3.61 & 1.373 & 3.96 & .767 & 4.17 & .778 & 3.78 & 1.043 & 3.91 & .996 \\
\hline Sarah Baartman District Municipality & 4.43 & .787 & 4.14 & 1.215 & 4.57 & .535 & 4.29 & .488 & 4.14 & .378 & 3.71 & 1.113 \\
\hline Total & 4.43 & .813 & 3.93 & 1.102 & 4.16 & .783 & 4.22 & .837 & 3.98 & .899 & 3.98 & 1.061 \\
\hline $\mathbf{P}=$ & \multicolumn{2}{|c|}{.766} & \multicolumn{2}{|c|}{.063} & \multicolumn{2}{|c|}{.343} & \multicolumn{2}{|c|}{.878} & \multicolumn{2}{|c|}{.834} & \multicolumn{2}{|c|}{.812} \\
\hline Effect size & \multicolumn{2}{|c|}{0.02} & \multicolumn{2}{|c|}{0.05} & \multicolumn{2}{|c|}{0.03} & \multicolumn{2}{|c|}{0.01} & \multicolumn{2}{|c|}{0.01} & \multicolumn{2}{|c|}{0.02} \\
\hline
\end{tabular}

In order to have a general perspective on the provincial outlook with regards to the relationship between recreation participation and mental health experiences, the total mean for each municipality was obtained and the average mean for all municipalities deri ved from the result. The results revealed that the municipality with the most mental health experience from recreation participation was Nelson Mandela Bay Metropolitan Municipality (4.24), followed by Sarah Baartman District Municipality (4.21), OR Tambo District Municipality (4.14), Buffalo City Metropolitan Municipality (4.12) and Joe Gqabi District Municipality (4.12), Chris Hani District Municipality (4.08), Alfred Nzo District Municipality (4.07) and Amathole District Municipality (4.01). The provincial (total from all municipalities) mean of 4.12 was then arrived at as an indication of how participation in recreation activities could impact on mental health experiences.

\section{Analysis of variance}

\section{Income levels and mental health experience}

Upon completion of the first section of the descriptive statistics, analysis of variance (ANOVA) was conducted to explore the relationship between income levels and the mental health experience of the respondents. The six key mental health factors (dependent variables) were established from literature as (happiness with self, better concentration, improved relationships, greater meaning and purpose of life, progress towards goals and peace with self). Three categories of the independent variable (annual household income levels) were defined as follows: category 1: less than R25000 (below the upper bound of poverty line), category 2: R25000 - 100, 000 (above the upper bound of poverty line) and category 3: more than R100, 000 (above subsistence level).

Table 4. Results of the descriptive statistics between income levels

\begin{tabular}{|c|c|c|c|c|c|c|c|}
\hline \multirow{3}{*}{$\begin{array}{l}\text { Mental health factor } \\
\text { Participation in recreation activities makes me }\end{array}$} & \multicolumn{6}{|c|}{ Income Level } & \multirow{3}{*}{ P-value } \\
\hline & \multicolumn{2}{|c|}{$(<\mathrm{R} 25,000) \mathrm{n}_{1}=89$} & \multicolumn{2}{|c|}{$(\mathrm{R} 25,000-\mathrm{R} 100,000) \mathrm{n}_{2}=139$} & \multicolumn{2}{|c|}{ (more than R100,000) $n_{3}=19$} & \\
\hline & Mean & Std Dev & Mean & Std Dev & Mean & Std Dev & \\
\hline Happy with myself & 4.39 & .834 & 4.45 & .818 & 4.47 & .697 & .866 \\
\hline Improve relationship with others & 3.98 & .825 & 4.26 & .726 & 4.26 & .872 & .024 \\
\hline Have greater meaning and purpose & 4.21 & .885 & 4.25 & .723 & 4.00 & 1.291 & .470 \\
\hline Progress towards my goals & 4.03 & .947 & 3.94 & .866 & 4.00 & .943 & .754 \\
\hline \multirow[t]{2}{*}{ Have Peace with myself } & 4.17 & .920 & 3.86 & 1.107 & 4.00 & 1.247 & .094 \\
\hline & & & & & & & 0.04 \\
\hline
\end{tabular}

The results were found to have a statistically significant difference at the $\mathrm{P}=04$, considering that this figure is within the $\mathrm{P} \leq .05$ significance level (Pallant, 2013). Further scrutiny of the data output revealed a statistically significant difference in the factor "improved relationship with others" between group 1 (n1) and group 2 (n2) at the $\mathrm{P}=.022$. The effect size, calculated using eta squared, that is,

$$
\begin{array}{cc}
\text { Eta squared }=\text { sum of squares between groups } & 5.305 \\
\text { Total sum of squares } & 276.899
\end{array}
$$

was also examined and found to be minimal at 0.02 . It can therefore be deduced from the effect size of 0.2 that, even though there was a statistically significant difference between income group 1 and 2 with regards to improvements in relationships, the effect size was assessed to be minimal (Cohen, 1988). The study thought it worthwhile to interrogate and explore the statistical variance in the variable employment status. This was done to find out if there was a statistically significant difference in mental health experience among the respondents based on employment status. The results obtained are presented in Table 5 below.

Similarly, the results indicated a statistically significant difference at the $\mathrm{P}=03$, considering that this figure is within the $\mathrm{P} \leq .05$ significance level (Pallant, 2013). The effect size, calculated using eta squared, that is,

Eta squared $=$ sum of squares between groups

Total sum of squares 
was also examined and found to be minimal at 0.02 . The result of the effect size of 0.2 also confirms that, despite there being a statistically significant difference between employment status mental health experience, the effect size impact was assessed to be minimal (Cohen, 1988). Results from the analysis of variance and effect sizes above clearly reveal that important insights can be derived from this study with regards to how community involvement in recreation can impact on mental health. The fact that the effect sizes are minimal only goes to illustrate that economic circumstances such as employment status and household income do not impede mental health benefits from accruing to communities that engage in recreation.

Table 5. Results for descriptive statistics for employment status

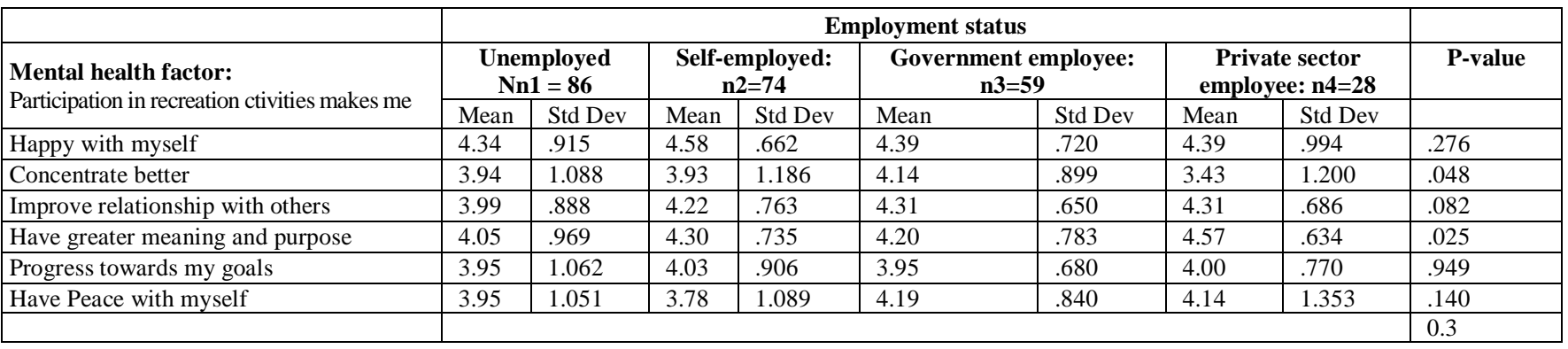

\section{CONCLUSION}

The purpose of this study was to explore the relationship between participation in recreation activities and mental health experiences among communities in the Eastern cape province of South Africa. The study was motivated, in part, by the high prevalence of mental health challenges in the province, but more so, by the significant pressure that the COVID-19 pandemic has brought to bear on inhabitants of the province and South Africa at large. The following conclusions can be drawn from the analysis presented in this study:

First of all, the high mean values $(3.93-4.43)$ obtained from the descriptive analysis reveal that it is credible to conclude that there is a positive correlation between participation in recreation activities and mental health experience. This conclusion is in line with previous studies (Lobo, 2011; Aksoy et al., 2017; Eskiler et al., 2019), but deviate from findings by Rundle et al. (2018) that tourism and recreation could have adverse effects on the mental health of participants. Secondly, the inter-community or municipality mean values (4.01 - 4.24) indicate that recreation participation would lead to benefits across communities, regardless of their geo-political location. This conclusion is also reached by Dillette et al, 2020, as they apply the PERMA model in exploring the nexus between vacations, happiness and wellness.

The fact that the mean score for the variable "happy" is quite high (4.43) indicates that participation in recreation can be instrumental in dissipating the tensions that trigger the deterioration of mental health in the first instance. Again, previous studies (Lobo, 2011; Dillette et al., 2020; White and Eyber, 2017; Mueller et al., 2019) agree with this proposition. It is also significant that the respondents in this study indicate that participation in recreation activities enables them to develop better relationships with other commu nity members. This leads to the conclusion that participation in recreation activities can stimulate a snowball effect of positive community relations. Studies by Kolappa et al. (2013) and Eskiler et al., 2019) reached a similar conclusion. The conclusion from the analysis of variance and the effect sizes is that mental health benefits from recreation participation go beyond economic situation of community members. This quite significant because previous studies (Statistics South Africa, 2019; Eastern Cape Socio-Economic Consultative Council, 2019) have revealed that unemployment and poverty are some of the major challenges confronting the Eastern Cape province.

\section{Implications}

The conclusions from this study provide implications for government, policy makers, health practitioners, community leaders and individuals as follows:

Foremost among the implications is role of government in the provision of quality mental health and recreation. The conclusions imply that recreation can be used as an instrument to enhance mental health.in local communities. This could be quite helpful in improving the quality of mental health in communities and the Eastern Cape province as a whole.

The second implication from this study relates to increase advocacy for a community approach to efforts towards improving the quality of mental health in the Eastern cape province. The shared sentiments of happiness, improved relationships, meaning and purpose among recreation participants clearly show that mental health benefits spread easily among groups of people.

Thirdly, policy implications from this study relate to the formalisation of recreation practice at community level. Therefore, policies that encourage recreation practice, put in place the necessary infrastructure and government involvement in community recreation e vents should be discussed, formally adopted and implemented.

The fourth implication from this study refers to the adoption of an all-stakeholder approach to recreation and mental health practice. This will ensure that all stakeholders see the need and potential gains from taking part in recreation activities as a means of improving mental health within communities. A silo approach tends to create suspicion and apathy.

Lastly, the conclusions from this study also imply that individual community members need to take responsibility in working towards improving their mental health by taking part in recreation activities. Community members could be held to sensitise community members on the potential benefits of recreation participation.

\section{Recommendations}

Based on the conclusions and implications of this study, the following recommendations have Recreation been put forward:

- practice should be formally endorsed by the provincial government as an instrument of community mental health upliftment. Evidence from this study suggests that this could boost happiness and improve relationships thereby reducing tension.

- It is also recommended that structures be put in place at the community and local government level to encourage and oversee recreation practice within communities. This bottom-top approach would motivate and place local communities at the centre of recreation activities and provide an opportunity for local people to decide which recreation activities interest them.

- It is further recommended that government provide infrastructure and recreation facilities within communities so that they are accessible to all community members. These recreation facilities should be complemented by events that are organised periodically within the province. A combination of recreation facilities and calendar of events would make recreation practice accessible and attractive to community members. 


\section{Limitations and future research}

Despite the robustness of the research process applied in this study, there are a few limitations that should be considered in the generalisation of its findings. Primary among these is the limited number of participants in the study. In order to generalise the findings of a study of this nature to the entire population of the Eastern Cape province, future studies should include a larger sample that is more representative of the population.

The impact of the outbreak of the COVID-19 pandemic and the subsequent "lockdown" poses another limitation to the findings of this study, considering that greater socio-economic pressure has been brought to bear on communities. With the number of deaths from the pandemic mounting and an increasing number of people anxious about their employment status, a similar study carried now could produce varying results. It is therefore advisable that further research be conducted to factor in the effects of the COVID-19 pandemic.

\section{REFERENCES}

Acha-Anyi, P.N. (2018). The foundation of tourism. Introduction to tourism planning and development: Igniting Africa's tourism economy (pp 1-18). Van Schaik Publishers, Pretoria, South Africa.

Acha-Anyi, P.N. (2020). Exploring the tourism phenomenon. Fundamentals of tourism: An African perspective (1-19). Van Schaik Publishers, Pretoria, South Africa.

Aksoy, Y., Çankaya, S., \& Taşmektepligil, M.Y. (2017). The effects of participating in recreational activities on quality of life and job satisfaction. Universal Journal of Educational Research, 5(6), 1051-1058. https://doi.org/10.13189/ujph.2017.050503

Aliyeva, Z., Sakypbek, M., Aktymbayeva, A., Assipova, Z., \& Saidullayev, S. (2020). Assessment of recreation carrying capacity of ILE-ALAT AU National park in Kazakhstan. GeoJournal of Tourism and Geosites, 29(2), 460-471. https://doi.org/10.30892/gtg.29207-482

Andersson, G., Carlbring, P., Ljótsson, B., \& Hedman, E. (2013). Guided internet-based CBT for common mental disorders. Journal of Contemporary Psychotherapy, 43, 223-233. https://doi.org//10.1007/s10879-013-9237-9

Bimerew, M. (2019). Information systems for community mental health services in South Africa. International Journal of Africa Nursing Sciences, 11, 100127. https://doi.org/10.1016/j.ijans.2019.01.001

Bradshaw, D., Norman, R., \& Schneider, M. (2007). A clarion call for action based on refined DALY estimates for South Africa. Editorial. South African Medical Journal, 97, 438-440. PMID: 17691472

Burns, J.K. (2011). The mental health gap in South Africa - a human rights issue. The Equal Rights Review, 6 (99), 99-113.

Chukhu, T. (2020a). The impact of airport experience on international tourists' revisit intention: A South African case. GeoJournal of Tourism and Geosites, 29(2), 414-427. https://doi.org/10.30892/gtg.29203-478.

Cohen, J.W. (1988). Statistical power analysis for the behavioural Sciences (2nd edn.). Hillsdale, NJ: Lawrence Erlbaum Associates.

Creswell, J. \& Clark, V. (2011). Designing and conducting mixed methods research. Thousand Oaks, CA: SAGE.

Datta, B. (2020). Factors affecting the satisfaction levels of medical tourists: A case study of Delhi national capital region. GeoJournal of Tourism and Geosites, 29(2), 628-635. https://doi.org/10.30892/gtg.29219-494

Dillette, A.K., Douglas, A.C., \& Andrzejewski, C. (2020). Dimensions of holistic wellness as a result of international wellness tourism experiences. Journal Current Issues in Tourism, 5(2), 1-17. https://doi.org/10.1080/13683500.2020.1746247

Dolnicar, S., Yanamandram, V., \& Cliff, K. (2012). The contribution of vacations to quality of life. Annals of Tourism Research, 39 (1), 59-83. https://doi.org/10.1016/j.annals.2011.04.015

Eskiler, E., Yildiz, Y., \& Ayhan, C. (2019). The effect of leisure benefits on leisure satisfaction: Extreme sports. Turkish Journal of Sport and Exercise, 21(1), 16-20. https://doi.org/10.15314/tsed.522984

Filep, S. (2014) Moving beyond subjective well-being: A tourism critique. Journal of Hospitality and Tourism Res 38: 266-274. https://doi.org/10.1177/1096348012436609

Fletcher, J., Fyall, A., Gilbert, D., \& Wanhill, S. (2018). An Introduction to Tourism. Tourism: Principles and practice (pp. 1-28), (6th ed.). Pearson Publishers, Edinburgh Gate. United Kingdom.

Ferguson, M.D., Lynch, M.L., Powers, S.L., Barrett, A.G., \& Mowen, A.J. (2019). The impacts of shale natural gas energy development on outdoor recreation A state wide assessment of Pennsylvanians. Journal of Outdoor Recreation and Tourism, 27(3), 342-356. https://doi.org/10.1016/j.jort.2019.100230

Gumus, H., \& Isik, O. (2018). The relationship of physical activity level, leisure motivation and quality of life in candidate teachers. International Journal of Progressive Education, 14(5), 22-32. https://doi.org/10.29329/ijpe.2018.157.3

Hair, J., Bush, R., \& Ortinau, D. (2006). Marketing research: Within a changing environment, McGraw-Hill. New York, United States of America.

Hartwell, H. (2015). Mental health and wellbeing. Perspectives in Public Health, 135(1), 36-54. https://doi.org/10.1177/1757913914558080

Herman, A.A., Stein, D.J., Seedat, S., Heeringa, S.G., Moomal, H., \& Williams, D.R. (2009). The South African Stress and Health (SASH) study: 12-month and lifetime prevalence of common mental disorders. South African Medical Journal, 99(5 Pt 2), 339-44. PMID: 19588796

Huppert, F.A. (2009). Psychological well-being: Evidence regarding its causes and consequences. Applied Psychology: Health and Well-Being, 1, $137-164$.

Kerimbay, B.S., Janaleyeva, K.M., \& Kerimbay, N.N. (2020). Tourist and recreational potential of landscapes of the specially protected natural area of Sharyn of the Republic of Kazakhstan. GeoJournal of Tourism and Geosites, 28(1), 67-79. https://doi.org/10.30892/gtg.28105-452

Kolappa, K. Henderson, D.C., and Kishore, S.P. (2013). No physical health without mental health: Lessons unlearned? Bulletin of the World Health Organisation, 9(1), 1-80. https://doi.org/10.2471/BLT.12.115063

Langviniene, N. (2014). Changing patterns in the health tourism services sector in Lithuania. 19th International Scientific Conference; Economics and Management, 5(3), 23-25. https://doi.org/10.1016/j.sbspro.2014.11.194

Lee, H.K., \& Fernando, Y. (2015). The antecedents and outcomes of the medical tourism supply chain. Tourism Management, 46, 148-157. https://doi.org/10.1016/j.tourman.2014.06.014

Leiper, N. (1979). The framework of tourism. Towards a definition of tourism, tourist and the touristic industry. Annals of Tourism Research, 6(4), 390-407. https://doi.org/10.1177/004728758001900184

Lobo, F. (2011). The work-leisure paradigm: The stresses and strains of maintaining a balanced lifestyle. World Leisure Journal, 48(3), 22-32. https://doi.org/10.1080/04419057.2006.9674451

Lund, C. and Flisher, A. J. (2009). A model for community mental health services in South Africa. Tropical Medicine and International Health, 14 (9), 10401047. https://doi.org/10.1111/j.1365-3156.2009.02332.x

Lund, C., Kleintjes, S., Kakuma, R., \& Flisher, A.J. (2010). Public sector mental health systems in South Africa: Inter-provincial comparisons and policy implications. Social Psychiatry Psychiatric Epidemiology, 45(3), 393-404. https://doi.org/10.1007/s00127-009-0078-5

Lund, C., De Silva, M., \& Plagerson, S. (2011). Poverty and mental disorders: Breaking the cycle in low-income and middle-income countries. Lancet, 378(9801), (11)60754-X. 1502-1514. https://doi.org/10.1016/S0140-6736

Madala-Witbooi, N. J., \& Adeniyi, O. V. (2019). Demographic and clinical profiles of admitted psychiatric patients of the East London Mental Health Unit in the Eastern Cape, South Africa. Medicine (Baltimore), 98(52), 183-99. https://doi.org/10.1097/MD.0000000000018399

Marion, S., Davies, A., Demsar, U., Irvine, R.J., Stephens, P.A., \& Longa, J. (2018). A systematic review of methods for studying the impacts of outdoor recreation on terrestrial wildlife. Global ecology and conservation, 22, 1-15. https://doi.org/10.1111/1365-2664.12700

Matlala, M., Maponya, M.L., Chigome, A.K., \& Meyer, J.C. (2018). Overview of mental health: A public health priority. South Africa Pharmacy Journal, 85(6) 46-53, S Afr Pharm J

Mouton, J. (2013). How to succeed in your master's and doctoral studies (pp. 44-61). Van Schaik Publishers. Pretoria, South Africa.

Mueller, J.T., Park, S.Y., Andrew J. \& Mowen, A.J. (2019). The relationship between self-rated health and local government spending on parks and recreation in the United States from 1997 to 2012. Preventive Medicine Reports, 13, 105-112. https://doi.org/10.1016/j.pmedr.2018.11.018 
Myers, J.E., Sweeney, T.J., \& Witmer, J.M. (2000). The wheel of wellness for counselling wellness. A holistic model for treatment planning. Journal of Counsel Development, 78, 251-266. https://doi.org/10.1002/j.1556-6676.2000.tb01906.x

Nicolaides, A., \& Grobler, A. (2017). Spirituality, Wellness Tourism and Quality of Life. African Journal of Hospitality, Tourism and Leisure, 6(1), 1-37. http://hdl.handle.net/10500/22740

Pallant, J. (2003). SPSS survival manual (5th ed.). McGraw Hill. Berkshire, England.

Pesonen, J., Laukkanen, T., \& Komppua, R. (2011). Benefit segmentation of potential wellbeing tourists. Journal of Vacation Marketing, $17,303-314$.

Petersen, I. (2000). Comprehensive integrated primary mental health care for South Africa. Pipedream or possibility? Social Science \& Medicine, 51, 321-334. https://doi.org/10.1016/S0277-9536(99)00456-6

Ramugondo, E., Lepere, R., \& Nebe, W. (2017). Decolonizing stigma and diagnosis as healing work. Health Tomorrow, 5(1), 1-23. https://doi.org/10.1080/23802014.2020.1762510

Rubenstein, C. (1980). Vacations, Expectations, Satisfactions, Frustrations, Fantasies. Psychology Today, 13(2), 62-76. https://doi.org/10. 1016/j.annals.2011.04.015

Rundle, A.G., Revenson, T.A., \& Friedman, M. (2018). Business Travel and Behavioral and Mental Health. Journal of Occupational \& Environmental Medicine, 60(7), 612-616. https://doi.org/10.1097/JOM.0000000000001262

Ryan, R., \& Deci, E. (2001). On happiness and human potentials: A review of research on hedonic and eudaimonic well-being. Annual Review of Psychology, 52, 141-166. https://doi.org/ 10.1146/annurev.psych.52.1.141

Skeen, S., Lund, C., Kleintjes, S., \& Flisher, A. (2010). Meeting the Millennium Development Goals in Sub-Saharan Africa: What about mental health? International Review Of Psychiatry, 22(2), 624-31. https://doi.org/10.3109/09540261.2010.535509

Stewart-Brown, S., Samaraweera, P.C., Taggart, F., Kandala, N.B., \& Stranges, S. (2015). Socioeconomic gradients and mental health: Implications for public health. The British Journal of Psychiatry, 206, 461-465. https://doi.org/10.1192/bjp.bp.114. 147280

Strümpher, J., van Rooyen, D., Topper, K., Andersson, L., \& Schierenback, I. (2016). Barriers to accessing mental health care in the Eastern Cape Province of South Africa. Africa Journal of Nursing and Midwifery, 16(1), 251-265. https://doi.org/10.25159/2520-5293/1487

Suárez, M., Barton, D.N., Cimburova, Z., Rusch, G.M., \& Onaindia, M. (2020). Environmental justice and outdoor recreation opportunities: A spatially explicit assessment in Oslo metropolitan area, Norway. Environmental Science \& Policy, 108, 133-143. https://doi.org/10.1016/j.envsci.2020.03.014

Sukeri, K., \& Emsley, R. (2015). Needs-based gap analysis for service transformation in the Eastern Cape. South African Journal of Psychiatry, 21(1), 3-7. http://dx.doi.org/10.7196/sajp.609

Tamminen, N., Reinikainen, J., Appelqvist-Schmidlechnerc. K., Borodulin, K., Mäki-Opase, T., \& Solina, P. (2020). Associations of physical activity with positive mental health: A population-based study. Mental Health and Physical Activity, 18, 1003-19. https://doi.org/10.3389/fbioe.2019.00378

Tribe, J. (2016). The economics of recreation, leisure and tourism (5th ed). Routledge, New York, USA.

Vaillant, G.E. (2012). Positive mental health: Is there a cross-cultural definition? World Psychiatry, 11(2), 93-99. https://doi.org/10.1016/j.wpsyc.2012.05.006

Wang, W.C., Wu, C.C., \& Wu, Y. (2013). Early-life outdoor experiences and involvement in outdoor recreational activities in adulthood: A case study of visitors in Da-Keng, Taiwan. Journal of Quality Assurance in Hospitality and Touris, 14(1-2), 66-80. http://www.tandfonline.com/doi/abs/10. 1080/1528008X.2013.749383

White, S.C., Eyber C. (2017) Positive Mental Health and Wellbeing. In: White, R., Jain, S., Orr, D., \& Read U. (Eds) The Palgrave Handbook of Sociocultural Perspectives on Global Mental Health (pp. 1-27). Palgrave Macmillan, London.

*** Department of Health (DoH). (1997). White paper for the transformation of the health system in South Africa. Accessed 09/06/2020. Available from https://www.gov.za/sites/default/files/gcis_document/201409/17910gen6670.pdf

*** Department of Health (DoH). (1997). National health policy guidelines for improved mental health in South Africa. Government press (pp. 1-15). Pretoria, South Africa.

*** Department of Health (DoH). (2013). National mental health policy framework and strategic plan 2013-2020. Accessed 09/06/2020 Available from file:///C:/Users/Staff/ AppData/Local/Packages/Microsoft.MicrosoftEdge_8wekyb3d8bbwe/TempState/Downloads/National\%20Mental\% 20Health\%20Policy\%20Framework\%20and\%20Strategic\%20Plan\%202013-2020\%20(1).pdf

***Eastern Cape Socio-Economic Consultative Council (ECSECC). (2019). Eastern Cape labour market overview. Accessed 11/06/2020. Available from https://www.ecsecc.org/documentrepository/informationcentre/ecsecc-labour-report-210619_73742.pdf

*** Food and Agriculture Organisation (FAO). (2020). Making rights a reality. Accessed 11/06/2020. Available from http://www.fao.org/focus/ e/rightfood/right 2 .htm

*** Global Wellness Institute (GWI). (2018). Global Wellness Tourism Economy. Miami, USA. Accessed 08/07/2020. Available from https://globalwellnessinstitute.org/wp- content/uploads/2018/11/GWI_GlobalWellnessTourismEconomyReport.pdf

*** National Wellness Institute (NWI). (2009). Accessed 12/06/2020. Available from https://nationalwellness.org/page/History

*** South African College of Applied Psychology (SACAP). (2020). The shocking state of mental health in South Africa in 2019. Accessed 09/06/2020. Available from https://www.sacap.edu.za/blog/management-leadership/mental-health-south-africa/

*** South African Depression and Anxiety Group (SADAG). (2020). Making mental health matter during COVID19. Accessed 09/06/2020. Available from http://www.sadag.org/images/newsletter/SADAG-Making-Mental-Health-Matter-during-COVID19_compressed.pdf

*** South African Human Rights Commission (SAHRC). (2018). Annual report for the year ended 2018. Accessed 15/06/2020. Available from https://www.sahrc.org.za/home/21/files/Annual\%20Report\%202018.pdf

*** Statistics South Africa (Stats SA). (2016). Eastern Cape Community Survey 2016 results. Accessed 11/06/202. Available from http://www.statssa.gov.za/?p=8035

*** Statistics South Africa (Stats SA). (2017). Statistics South Africa on poverty trends in South Africa. Accessed 11/06/2020. Available from https://www.gov.za/speeches/statistics-south-africa-poverty-trends-south-africa-22-aug-2017-0000?gclid=Cj0KCQjwrIf3BRD1ARIsAMuugNtVYnX07N4wvEch8WH0LVvcLSt_KHn8_xVY2-gr8kOnrGuo961oocaAmgGEALw_wcB

**** Statistics South Africa (Stats SA). (2019). Five facts about poverty in South Africa. Available from http://www.statssa.gov.za/?p=12075

*** Statistics South Africa (Stats SA). (2020). Loss of income resulting from the COVID-19 pandemic may lead to higher levels of food insecurity SA Accessed 11/06/2020. Available from http://www.statssa.gov.za/?p=13327

*** World Health Organisation (WHO). (2004). Promoting Mental Health: concepts, emerging evidence, practice. Accessed 09/06/2020. Available from https://www.who.int/mental_health/evidence/en/promoting_mhh.pdf

*** World Health Organisation (WHO). (2013). Investing in mental health: evidence for action. Accessed 12/06/2020. Available from https://apps.who.int/iris/bitstream/handle/10665/87232/9789241564618_eng.pdf;jsessionid=49753F119D8DB2EE916BE0CB8DD0180F?sequence=1

*** World Health Organisation (WHO). (2018). World health statistics 2018: Monitoring health for the Sustainable Development Goals (SDGs). Accessed 12/06/2020. Available from https://apps.who.int/iris/bitstream/handle/10665/272596/9789241565585-eng.pdf

*** United Nations Development Programme (UNDP). (2015). Sustainable development goals. Accessed 09/06/2020. Available from file:///C:/Users/Staff/AppData/Local/Packages/Microsoft.MicrosoftEdge_8wekyb3d8bbwe/TempState/Downloads/SDGs_Booklet_Web_En\%20(3).pdf 